Article

\title{
Sustainable Development Compromise[d] in the Planning of Metro Vancouver's Agricultural Lands-the Jackson Farm Case
}

\author{
Jonathan Jackson $^{1, *}$ and Meg Holden ${ }^{2}$
}

1 Urban Studies Program, Simon Fraser University, 515 West Hastings Street, Vancouver, BC V6B 5K3, Canada

2 Urban Studies Program and Geography Department, Simon Fraser University, 515 West Hastings Street, Vancouver, BC V6B 5K3, Canada; E-Mail: mholden@sfu.ca

* Author to whom correspondence should be addressed; E-Mail: jrjackso@sfu.ca; Tel.: +1-778-229-2667.

Received: 13 August 2013; in revised form: 24 September 2013 / Accepted: 28 October 2013 / Published: 12 November 2013

\begin{abstract}
This research provides analysis of the case of the Jackson Farm development application, embedded within the particular dynamics of the municipal, regional, and provincial sustainability land use policy culture of the Metro Vancouver region, in Canada. Within a culture of appreciation of the increasing need for sustainability in land use policy, including the protection of agricultural lands at the provincial level through the Agricultural Land Reserve (ALR), to urban intensification and protection of the green zone at the regional scale, lies a political conflict that comes into focus in individual land use decisions, within municipalities struggling for autonomy. This case is neither driven strictly by "the politics of the highest bidder" nor by policy failure; the case of the Jackson Farm is instead a case of the challenges of implementing inter-governmental coordination and collaborative governance in a context of both significant sustainability policy and urban growth. The process can be seen to follow an ecological modernization agenda, seeking "win-win" alternatives rather than recognizing that typical compromises, over time, may tip the direction of development away from sustainability policy goals. Understanding the twists, turns, and eventual compromise reached in the case of the Jackson Farm brings to light the implications of the shift in the regional planning culture which may necessitate a less flexible, more structured prioritization of competing goals within plans and policies in order to meet sustainability goals. We highlight this, and present an alternative implementation process within the existing policy regime with potential to aid the specific goal of agricultural land protection.
\end{abstract}


Keywords: sustainable development; farmland protection; food security; urban sprawl; agricultural land reserve; regional planning; Vancouver; Canada

\section{Introduction}

Around the world, the spatial extent of cities is growing faster than population growth. Farmland is being lost in the process, with small farms particularly vulnerable. British Columbia's (BC) most arable lands are found in Metro Vancouver, and policy advances since the 1970s at provincial, regional and municipal scales have situated the region in a widely recognized leadership position in combating urban sprawl, promoting compact and polycentric urban systems, and protecting farmland value in balance with urban development [1-4]. In terms of the argument we build here, the key has been advancing an argument for sustained agricultural land use as an essential component of a sustainable urban system that can contribute to the protection of the landscape and sustainable urban form, generate employment, and ensure food security and sovereignty. Policy in Europe and in a select few other North American jurisdictions, such as Portland, has attempted to do the same in the same time period [5-9]. More frequently, particularly in the case of the U.S., such attempts have failed to change predominant sprawling development patterns. Excessive complexity of governance structures and jurisdictional battles often take a significant measure of the blame [10,11].

Within urban Canada, the Vancouver region is unique in witnessing net population densification over the 1990s [11]; and the majority of new housing being constructed in nearly all regional municipalities is medium-high density, not conventional suburban single family home dwellings [12]. The existence of three interacting government layers of effective urban policy and planning, and the collaborative and consensus-oriented spirit with which these have been applied, is credited with much of this success. Despite this aggregate success, an investigation of the detail of specific applications of agricultural protection and urban development policy reveals a fraying policy consensus that may need further support in order to continue to function in a more densely-populated, riskier future. As Taylor and Burchfield state: "Even if guided by coherent packages of plans and policies, the development of land occurs through countless parcel-level decisions made by multiple actors-planners, politicians, landowners, developers, builders, banks, insurers, and end-purchasers - each of whom operates with imperfect information in an ever-changing context" ([11], p. 55). The Jackson Farm case connects Metro Vancouver's aggregate comparative success in containing urban sprawl onto local agricultural lands with locally-specific insight into the challenges of implementing a complex policy agenda involving multiple levels of government and a collaborative approach. We conclude that improvements are needed in the process of implementing sustainable development policies and practices for farmland protection policy and make some suggestions for achieving this.

Municipal consent to be bound to the tenets of regional and provincial farmland and urban development planning appears now to be strained, not only in the municipality we will discuss in this case study, but also elsewhere on the urban fringe. On the region's southern edge, in Surrey, a group of landowners has applied to remove 37 acres from the Agricultural Land Reserve (ALR), with no indication of the proposed new land use; other local residents have mobilized to oppose this 
action [13]. In Langley Township, on the eastern fringe, local government has rezoned 180 acres, much of which lies within the ALR and outside the urban containment boundary, for the development of a new University District housing development. The regional government has initiated legal proceedings against the municipality. In a tacit plea to return to the kind of collaborative planning behaviour upon which Vancouver's regional model is based, a councillor from the inner suburb of Richmond commented on the Langley case in the news: "It's time Langley held the line too. If we in Richmond did what they're doing ... we'd have about 2000 acres of farmland threatened" [14]. The Jackson Farm case demonstrates how Metro Vancouver is like other regions in the world, where sustainable development policies to protect farmland can be undermined by private interests that often influence local political decisions, and also reveals the pernicious nature of sustainability compromises that have become popular in contemporary sustainability policy implementation. At the same time, the case demonstrates the value of intergovernmental coordination, when coupled with rigorous implementation standards, for the protection of farmland in line with the demands of urban growth.

\section{Case Study Methodology and Hypothesis}

The research reported here consists of an embedded case study analysis, where the unit of analysis is the set of land parcels constituting Jackson Farm, and the applications to change the land use and zoning of these parcels. This case is embedded within municipal, regional, and provincial policy contexts which have different processes and provisions related to the protection and conversion of agricultural land. This approach is well-suited to this research, as in many comparable cases of sustainable development compromises, by affording detailed, context-rich understanding of the complex social and political processes in the resolution of this particular land use challenge. The research results have the potential to improve sustainable development policy processes by revealing the unanticipated outcomes, built-in inconsistencies [15] and hidden rationalities [16] operating in this particular case.

Yin [17] promotes the disciplined use of the embedded case study as a means to "add significant opportunities for extensive analysis, enhancing the insights of a single case." Rather than producing a straight-forward refusal or failure to refute a research hypothesis, case study research presents analyses of "the reality behind appearances, with contradictions and the dialectical nature of social life" ([18], p. 39), that is not dissociated from "the flesh and bones of the everyday lifeworld" ([19], p. 7). In other words, case study research is not only a strategic supplement to quantitative research but also an essential approach in the quest to answer certain kinds of research questions, particularly process-oriented questions [20]. The holism and contextualization offered by a case study approach offers the close reading of the particularities of a case as these details are embedded within the context in which they are experienced, which together constitute what Snow and Anderson ([21], p. 152) call a "cultural system of action." The understanding of these particularities and contingencies brings reliability to the research by way of transparency [22]. Because of the ability to take these contingencies into account, case study research has often facilitated effective broader generalization [23,24].

The Jackson Farm case can be considered not a typical case but a critical case that has potential cascading effects on other development application processes in the Vancouver region and other regions with similar growth pressures and sustainable development policy goals. Critical cases, or 
cases that stand out as exceptional compared to most, are useful "to illuminate how the more general social process under discussion works" ([19], p. 16). Case analysis of the Jackson Farm land use dispute includes review of relevant government documents including staff reports, public hearing agendas and minutes, bylaws, policies, legislation, related documents and news articles; and semi-structured interviews with representatives from each of the three levels of government (local, regional, provincial) who had detailed involvement with the Jackson Farm case. Procedures followed and perspectives offered by each of the involved levels of government are pieced together based upon triangulation of data sources. The case is presented in chronological order, documenting how the case diverged from the expected process based upon a strict understanding of the relevant agricultural land protection, regional growth management, and local planning policies. This method of analysis allows the clear delineation of divergent viewpoints on issues, where they exist [25-27].

The analysis is presented in narrative style, supplemented by schematics. The narrative presentation of qualitative data is intended to communicate vividly the research results, remaining as authentic as possible to the form in which the process portrayed was experienced. Orum et al. ([19], p. 21) favor the narrative technique for its ability "to get at the human understandings that underlie the action" and to allow the reader to "grasp the nature of social action as it has been experienced by people themselves". Based upon further analysis of how the case evolved at each level and diverged from the expected process, the nature of the sustainable development compromise is presented in terms of its implications for the future of the policy and planning approach employed, and a revised implementation process is proposed which is expected to support stronger farmland protection results. In this way, this paper tests the hypothesis that the Jackson Farm case provides a valuable illustration of the potential and limits of the application of a collaborative intergovernmental approach to protecting farmland, supported by a strong regional planning regime, within a context of urban growth. Despite regional planning successes in the aggregate, Metro Vancouver's ability to protect its agricultural land resources depends critically upon more careful and strict attention to the implementation of three layers of land use and agricultural land protection policy, under conditions of a potentially shifting planning culture.

\section{Review of Literature}

The case study analysis is grounded in secondary and archival research into the importance of land use policy for protecting food security, the question of sustainability compromises in urban and regional planning, and the history of British Columbia's Agricultural Land Commission and regional planning in metropolitan Vancouver. All three areas of research are reviewed next.

\subsection{Land Use Planning and Food Security}

During the World Food Summit in 1996, Canada and other participating countries reached a consensus that: "Food security exists when all people, at all times, have physical and economic access to sufficient, safe and nutritious food to meet their dietary needs and food preferences for an active and healthy life" ([28], p. 9). The concept of "maintaining food security" necessitates "identifying vulnerable households, communities and regions that are en route to having a crisis of either availability or access" ([29], p. 1389). At regional levels, maintaining food security needs to consider precautionary actions for food production futures to ensure that risks emergent from phenomena such 
as climate change, environmental degradation, and the exhaustion of finite resources do not compromise people's ability to feed themselves. The related notion of food resilience involves the quantification of the longevity of food supplies within a city region's boundaries in the case of external supply shut-off [30]. The notion of food sovereignty builds further on this concept, toward an obligation for state intervention supporting the human right to feed oneself [31]. City regions like Metro Vancouver rely on agro-industrial food systems, industrialized processes that use chemical, mechanical, and energy inputs for nearly every stage of food production, transportation, packaging and storage [32]. Reliance on this oil dependent agro-industrial food system poses a risk to Metro Vancouver's future ability to maintain food security, alongside a rationale for the introduction of regional food sovereignty policy considerations, as the impacts on this system from forthcoming oil shortages, economic and climate shocks are unknown, but potentially large.

The Metro Vancouver region is part of the Lower Fraser Valley, and a 1972 study of the agricultural geography of British Columbia noted these lands to be the most important agricultural lands in the entire province, as well as subject to the highest degrees of land speculation [33]. According to the BC Ministry of Agriculture and Lands 2006 Food Self-Reliance study, BC farmers produce $48 \%-53 \%$ of the total foodstuffs needed in the province [34], demonstrating external reliance on food imports. Given the dependence of the agro-industrial food system upon cheap supplies of finite crude oil resources, Wright suggests that the food security crises endured by Cuba when the country's oil supplies ceased virtually overnight during the dissolution of the Soviet Bloc may foreshadow the experiences that many countries will face in a post-Peak Oil future [32]. If future generations are to maintain food security, in the event of oil shortages or other catastrophe, it is critical that agricultural lands be protected from urban sprawl $[35,36]$. Given that an average of five hundred years are needed for the accumulation of 2.5 centimetres of arable soils and that such soils account for only approximately $11 \%$ of land cover worldwide, their destruction is essentially irreversible [37,38]. Protection of these lands is at the heart of promoting a region's ability to maintain food security $[39,40]$. It is in this context that food sovereignty movements obligate the state to ensure preservation of and access to local farmland as part of a human right to feed oneself [31].

\subsection{Sustainability Compromises, Land Use Planning and Ecological Modernization}

Planning for sustainable development can be defined as "a dynamic process in which communities anticipate and accommodate the needs of current and future generations in ways that reproduce and balance local social, economic, and ecological systems, and link local actions to global concerns" [41]. In the context of contemporary cities, sustainable development requires land use practices that at least bridle urban sprawl [42] and "move from a dispersed form to a structured, diverse, compact form" [43]. In relation to food, a complete espousal of sustainable development would require cities to develop not in relation to global trade networks but primarily as bioregions where communities have most of their "needs met through a local and regional food supply system based on low input and organic agriculture" [43].

The enactment and implementation of sustainable development policy, however, can be influenced by the politics of self-interest in a marketplace that summons competition between individuals over scarce resources, with little consideration for the long term or common property resources [44]. 
In relation to planning and land-use policy at the local government level this can result in political decisions becoming developer-driven, rather than rooted in sustainable development notions of the collective good [44,45]. The disjuncture between sound growth management policy, and poor and contested implementation of this policy, experienced in urban regions from Lisbon to Portland, bears witness to this trend [8,9]. Moreover, not only do government and developer objectives compete, but different levels of government with overlapping and contested authority apply different priorities and tests to effective policy implementation. The power that policy can hold in this context goes only as far as the strength of efforts in sound implementation.

Policies to promote sustainable land use are often politically challenging. In uncertain and overdetermined contexts and futures, "policymakers can, at best, only argue that if $\mathrm{X}$ is done they hope $Y$ will come about" [46]. This is an insufficiently persuasive argument in times of fiscal constraints, competing agendas, and short policy attention spans. Instead, typically, what policymakers working under these constraints seek is a means to put land use policy on the path toward sustainability in a revenue-neutral way that does not appear to threaten economic growth. This move may take form in policy that dictates for development to cause "no net loss of agriculturally zoned land". By encouraging land swapping for development desired on agriculturally zoned land without explicit attention to the agricultural potential of the replacement land, this policy approach neither optimizes sustainable land use goals such as "no loss of agricultural opportunity", nor economic goals of maximizing all land values. Instead, it is a move toward ecological modernization, a preference to seek "win-win" alternatives that admit no compromise between environmental and economic goals, but seek to offer mutual and simultaneous benefit to both $[47,48]$. The opportunity lost within ecological modernization strategies is the opportunity to consider alternative resource and economic futures, with new determinants and measures of economic, environmental, and social benefit. Ultimately, such "win-win" solutions are a part of what economist David Pearce constituted as weak sustainability. In contrast, what is absent from the contemporary sustainable development policy sphere is striving for what Pearce called strong sustainability, initiatives that seek to preserve critical natural capital—fundamental elements of social value which cannot be substituted or swapped, like arable soil—so that future generations inherit a wealth of resources that will provide economic opportunity and social and environmental justice [49].

\subsection{BC's Agricultural Land Reserve and Metro Vancouver Regional Governance: A Brief History}

By 1972, public outcry over the erosion of farmland, particularly in the southern portion of British Columbia, was sufficient to support a successful challenge by the provincial New Democratic Party (NDP) for provincial leadership. It was the first time the NDP had formed government in BC [50]. The NDP created the Land Commission Act to "stop the rezoning of agricultural land for non-farming purposes" [51]. This established the Provincial Agricultural Land Reserve (ALR) to define protected agricultural areas, totaling about five percent of British Columbia's land base [52]. Presiding over the ALR was the Agricultural Land Commission, an independent body responsible for consideration of any application for a land use change on ALR land.

During the same era, to deal with rapid urbanization, the provincial government created regional districts that functioned parallel to local governments and had a planning mandate [53]. Following this 
move, in 1975 the Greater Vancouver Regional District (GVRD, referred to here also as Metro Vancouver, the name the agency assumed as of 2007) successfully struck a Livable Region Plan [54]. This followed on the heels of a 1963 study by the Lower Mainland Regional Planning Board which argued that "without intervention, the supply of urban land would be exhausted by the end of the millennium, and that the best option was to pursue a region-wide policy of infill and redevelopment of existing urban areas, the comprehensive protection of agricultural land whereby only fully serviced greenfield development would be permitted, and the direction of growth to self-sufficient 'regional towns" " [11].

Strong regional planning powers for the GVRD were short lived. A contentious 1979 land use amendment application to convert 142 hectares of ALR, known as the Spetifore Lands, to urban uses resulted in "the longest land use dispute hearing in Canadian history over efforts by developers to build on farmland for urban use" [55]. The Province rescinded regional planning authority and subsequently nullified all regional plans in 1983, claiming that regional districts were trespassing on municipal jurisdiction [56]. Hodge and Robinson offered a different interpretation of this move as a move to increase the powers of the Social Credit government then in power [53]. The Spetifore Lands case illustrates the deep-seated context for the Jackson Farm case to be presented here: a contentious political interplay between municipal, regional, and provincial planning powers, political priorities and development pressures, in relation to preserving agricultural land uses.

When the NDP took power of the provincial cabinet again in 1991, they "almost immediately started work on legislative changes that would give regional plans more authority" [54]. They also acted quickly to restore power to the ALC [50]. By 1995, the NDP had implemented the Growth Strategies Statutes Amendments Act, "to provide a provincial legislative context for growth management planning" [53] at a regional scale. In January 1996, Metro Vancouver's Livable Region Strategic Plan (LRSP) was approved. The LRSP identified regional town centres to focus development, using twin principles of Building Complete Communities and Achieving a Compact Metropolitan Region, as well as Increasing Transportation Choice and, importantly, creating a Green Zone designation to protect approximately two-thirds of the region's land base from urban development, including those lands within the ALR.

Although the ALC has not prevented sprawl into the urban-rural fringe of metropolitan Vancouver, it has successfully constrained the extent of sprawl [57,58]. Currently the ALR includes approximately 4.76 million hectares province-wide; 60,508 hectares of ALR land are situated in Metro Vancouver, or approximately $21 \%$ of Metro Vancouver's total land area [52]. The ALC notes that the extent of the ALR is approximately the same as it was at its inception, which is more remarkable considering that estimates put the rate of agricultural land conversion at about 1000 ha per year prior to the establishment of the ALR [59]. However, a report by the David Suzuki Foundation suggests that the ALR's success province-wide is only due to the fact that exclusions of land in the more fertile areas have been replaced over time by inclusions of less productive land in Northern British Columbia [60]. Over the three decades since the ALR's inception, the total amount of ALR land in Metro Vancouver has been reduced by 6331 hectares or $9.5 \%$ [52]. 


\section{Analysis: The Jackson Farm Case as a Sustainability Compromise}

The detailed review of the case of the conversion of the Jackson Farm, provided below, provides a means to understand both the strengths of the interacting, intergovernmental agricultural protection, regional planning, and municipal planning policies in Metro Vancouver, and the limits to integration, correspondence, and effectiveness in the way in which these policies have been implemented. The path to the eventual sustainable development compromise reached is laid by steps taken by the development applicant through three levels of government; far from a case of policy failure, it is instead a case of the challenges of implementation of strong policy in a contemporary growth context. This case analysis permits us to present an alternative implementation process for the policy suite that has good potential to lead to stronger outcomes for agricultural land protection. As for the compromise itself, this can be understood as evidence of ecological modernization in a context of collaborative governance and the quest for a "win-win" scenario involving acceptable trade-offs. The very notion of acceptable trade-offs, however, in the context of loss of agricultural land, represents a divergence from the consensus-based planning culture that gave birth to the agricultural protection policy suite as it exists. The progression of the case, and the way in which the compromise is argued, also brings to light a potential shift under way in the regional planning culture, which could necessitate a shift in plan and implementation approach.

\subsection{Jackson Farm: Context and History}

Established as the sixth municipality in British Columbia in 1874, today the District of Maple Ridge is a suburban Metro Vancouver municipality with a population over 75,000 [61]. In 1897, the Jackson family (of no relation to this paper's author) established Jackson Farm as a 70 cow dairy farm and extensive orchard. It was later converted to a cattle ranch [62-66]. Throughout the twentieth century the legal boundaries of Jackson Farm were altered through subdivisions and road dedications that resulted in the bisecting of the single legal parcel by Jackson Road, leaving 15.07 hectares to the west (Lower Jackson Farm) and 8.96 hectares to the east (Upper Jackson Farm). The topography of Jackson Farm includes riparian corridors with creeks and marshland (Figure 1).

Figure 1. Lower and Upper Jackson Farm Map, showing aerial photography, with blue lines denoting watercourses (source: District of Maple Ridge, Ridgeview Mapping, 2011, adapted with permission; with notations by Jonathan Jackson).

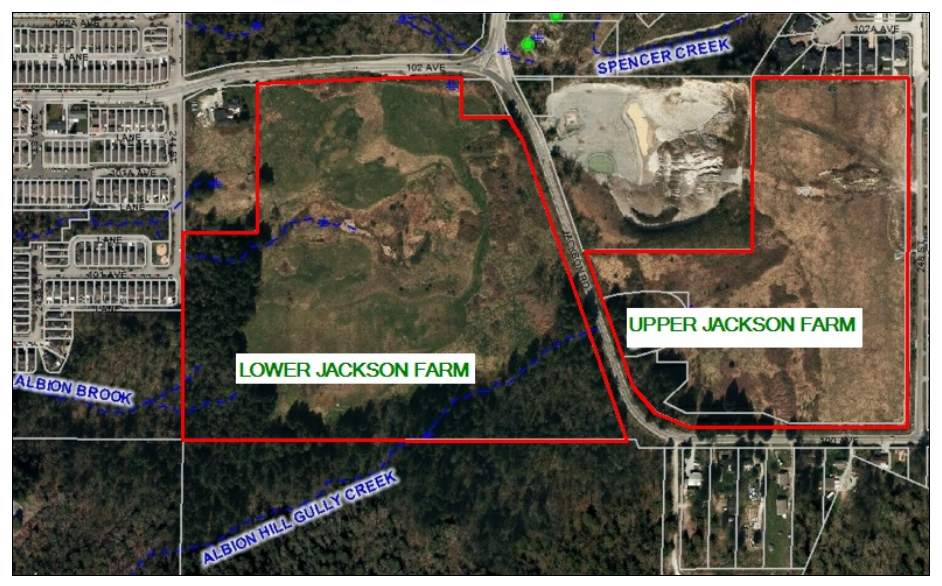




\subsection{Jackson Farm: Establishing the ALR Boundaries}

The merits of establishing the ALR boundaries between 1973 and 1975 were premised initially upon protecting the agricultural land that was most critical to food production: "the capability and suitability of the land, its present use, local zoning and input from public hearings" [52]. During the establishment of the ALR, Lower Jackson Farm was included, likely owing to the fact that it was being actively farmed, was part of a larger farm area, and had good arable soils. Upper Jackson Farm, with marginally inferior soils, was not included in the ALR, likely because it was not cleared for active farming at that time; based on soil typology it qualified.

\subsection{Jackson Farm and the Thornhill Urban Reserve}

While not included in the ALR, Upper Jackson was granted interim protection from development by the early 1980s, through Maple Ridge's planning for the Thornhill Urban Reserve (Figure 2). The Thornhill Urban Reserve was intended to impose several critical criteria upon potential rezonings, including the completion of an area plan, environmental surveys, and attainment of key municipal development milestones. Accordingly, the Thornhill Urban Reserve policies were outlined as sustainable development pillars in the regional context statement of Maple Ridge's Official Community Plan (OCP), indicating Maple Ridge's plan to conform with the regional plan [67]. Deviations from this would ultimately require regional approvals. Notably, policy 3-26 of the District's 2006 OCP [67] stated that urban development could not occur within the Urban Reserve until both: the population had reached a threshold 100,000 population and the existing urban area approached build-out [68]. Furthermore, policy 3-27 (c): (iv) and (v) [67] required in depth assessment studies for agriculture and aquifer ground water. The Thornhill Urban Reserve lies directly north of a large stretch of land designated Agricultural, containing numerous ALR-protected farms. The Thornhill Urban Reserve is also located above an aquifer that supplies adjacent farmland with water for irrigation.

Figure 2. Thornhill Urban Reserve, noting Upper Jackson Farm as Subject Property (source: District of Maple Ridge, 2006; with notations by Metro Vancouver, adapted with permission).

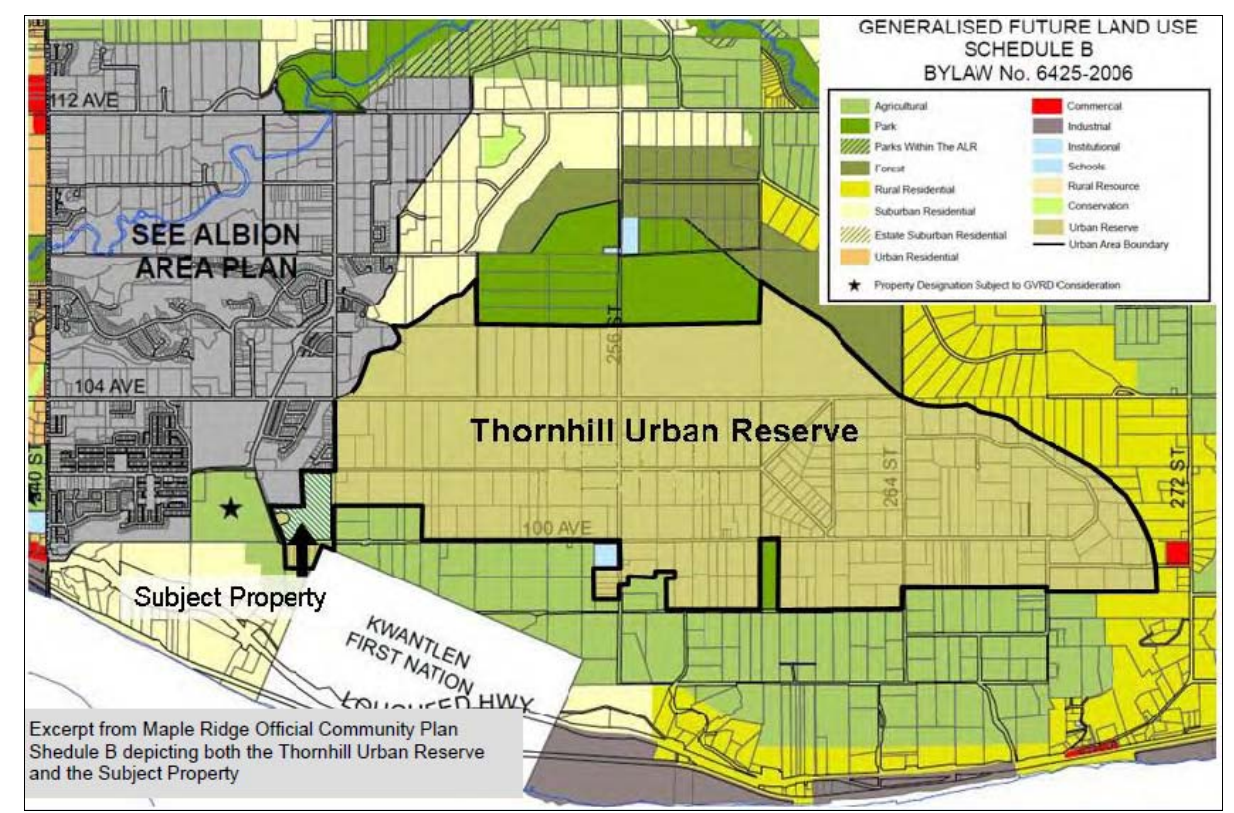




\subsection{Lower Jackson Farm: ALR Exclusion}

Jackson Farm was actively farmed until the 1996 death of a son of the farm's founders, Vin Jackson, when a lengthy court controversy took place over the estate, eventually leading to the property being put up for sale [62,66]. On 28 November 2001 a contract of purchase was accepted by the eighteen heirs of Jackson Farm, stipulating numerous terms and conditions, including that the property be removed from the ALR and also stripped of its Park designation, amended to Residential in the District of Maple Ridge's OCP. At this time, there was no mention of the need for amendments to Metro Vancouver's Green Zone to permit residential uses.

Responding to these terms and conditions, the District of Maple Ridge did not recommend acquiring the Jackson Farm at that time, but could not support a re-designation of the lands for compact residential uses, and preferred instead to re-designate the lands Agricultural; and furthermore stated that a requested letter of support for the proposed ALR exclusion could not be provided [69]. Nevertheless, the developer with the contract to purchase the farm hired Damax Consultants Ltd. to proceed with an ALR exclusion application (Figure 3).

Figure 3. Application Flow Chart (not including matters of provincial interest) (source: Jonathan Jackson, 2012).

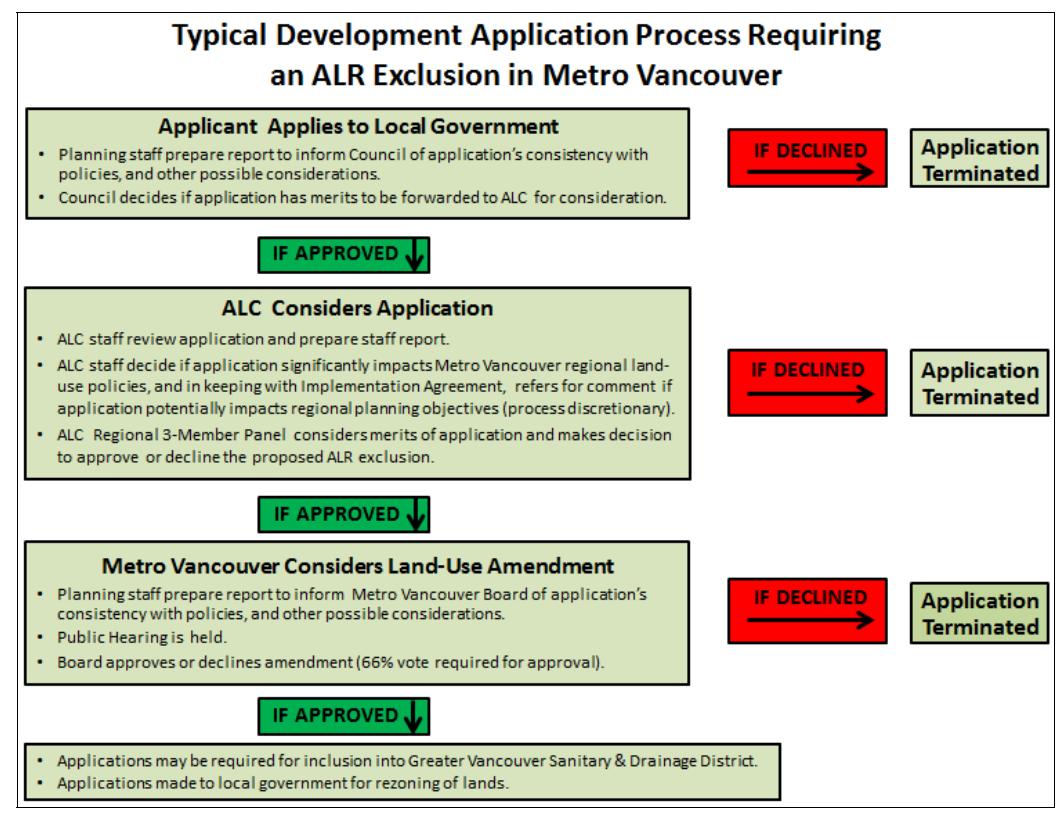

The District of Maple Ridge staff report to Council on the ALR exclusion application noted receipt of five letters of opposition, one with a forty-one member petition attached; that the application appeared to be in conflict with policies pertaining to the District's OCP as well as those pertaining to the ALR; and clarified that although the property was designated Park in the OCP it was never recommended for exclusion from the ALR [69]. The report also stated that "the property [was] currently under use as pasture, with cattle and horses roaming the site" ([69], p. 3). Finally, the report referenced The Heritage Resources of Maple Ridge 1998, noting the property's high heritage importance to cultural history, receiving the maximum possible rating for the visual or symbolic 
importance of its landscape. In closing, the report "recommended that application AL/087/02 [Jackson Farm ALR exclusion] not be authorized to proceed to the Land Reserve Commission" ([69], p. 6).

Council directed staff to respond to their questions in a second report, dated 17 April 2003. Council's questions primarily pertained to the Jackson Farm's potential as a future park, as well as land use planning in the subject area [70]. In this report, among other confirmations of the soil quality and heritage value of the site, it was noted that the applicant had updated the development proposal to increase the amount of proposed parkland from $48 \%$ of the total site area to $56 \%$ (Figure 4 ). Most of the proposed parkland was in fact not suitable for development, including areas subject to environmental and topographic constraints, such as creeks, marshland, and steep terrain (Figures 4 and 5).

Figure 4. Proposed Subdivision of Lower Jackson Farm (source: Agricultural Land Commission, 2003, adapted with permission).

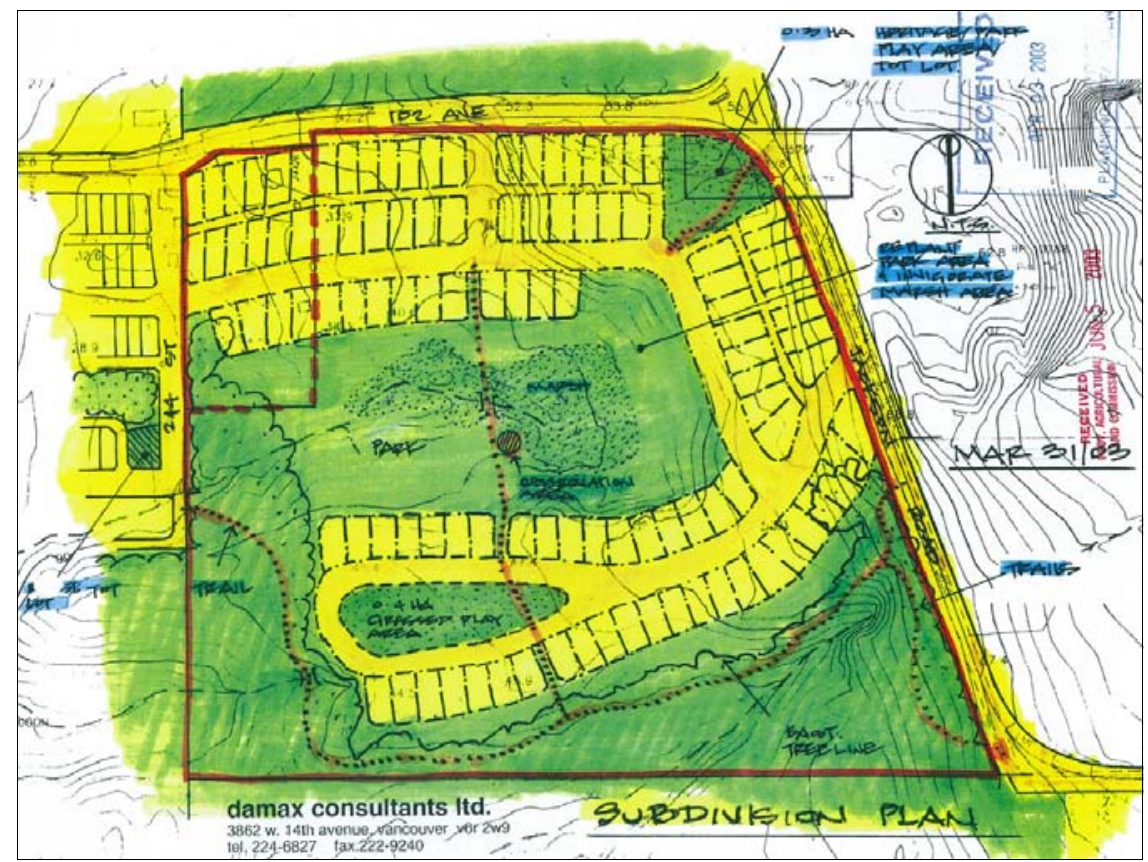

Figure 5. Presence of Creeks on Jackson Farm (source: District of Maple Ridge, Ridgeview Mapping, 2011, adapted with permission; with notations by Jonathan Jackson).

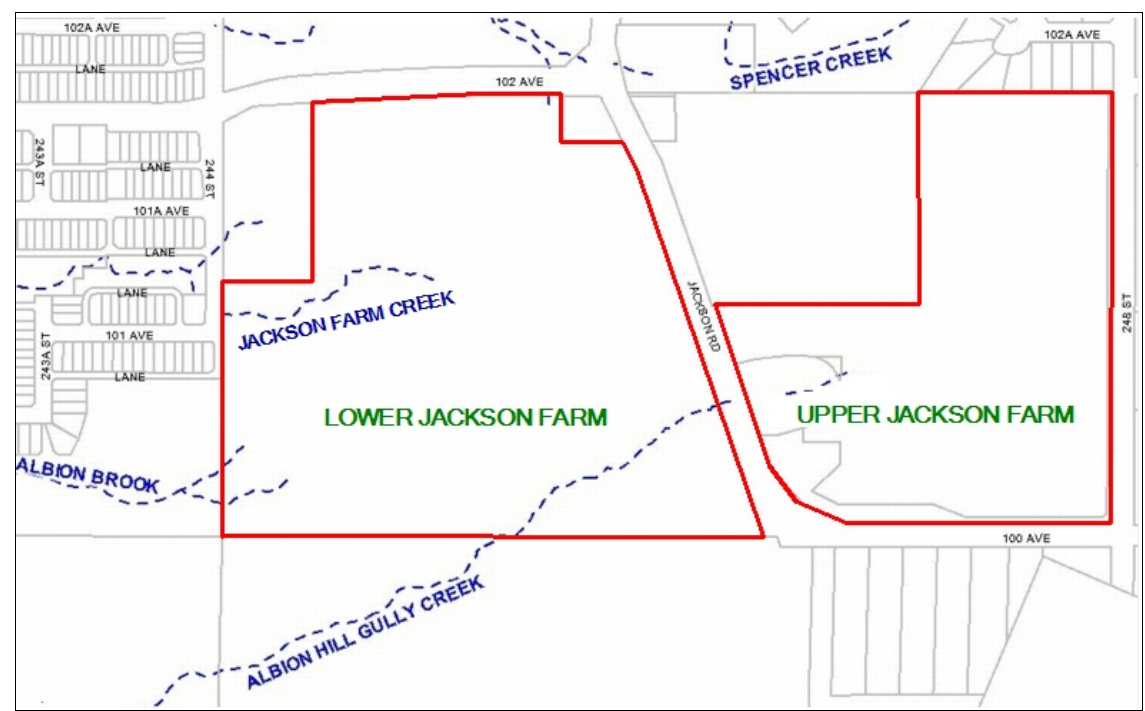


Maple Ridge planning staff consistently opposed the application to exclude Lower Jackson Farm from the ALR, premising its position on numerous policy conflicts that included negative impacts on agriculture as well as heritage considerations. Council, nevertheless, carried a motion to authorize the application to proceed to the ALC for consideration. Only Councilors Craig Speirs and Candace Gordon opposed the motion. Speirs was quoted in the local Maple Ridge News as "insist[ing] that any farmland should be preserved for food production," and that "the highest and best use for this property...is agricultural" ([65], p. 23). Similarly, Councilor Gordon was quoted in the Maple Ridge Pitt-Meadows Times ([71], p. 5) as saying "when we have land suitable for agriculture...we need to protect it."

Once the application had been forwarded to the ALC, a staff report dated 31 July 2003 made the following recommendations for the Commission to consider when reviewing the exclusion application:

- The majority of the subject property has good agricultural capability and has previously been used for farming — only 15\% is non-arable - $2 / 3$ is improved or improvable to Class 2 or 3 soils.

- Many of the local residents oppose the proposed exclusion and residential subdivision.

- The subject property is located at the edge of the urban boundary between agricultural land and residential subdivisions.

- Bringing a residential subdivision into an ALR farming area could create rural residential conflict as well as could increase pressure from neighbouring properties for similar applications.

- Exclusion of subject property will isolate one Class (3DT) 1.2 ha parcel from other ALR land;

- On the other hand, the subject property and adjacent ALR lands are isolated from the main part of this ALR block by an Indian Reserve (See Figure 2 for location of Kwantlen First Nation Indian Reserve, which also is situated within the ALR).

- GVRD [now Metro Vancouver] has not been consulted regarding removal of this key link from the GVRD Green Zone (The report provided a reference to the Implementation Agreement (Memorandum of Understanding), noting that the Commission was to provide the GVRD a chance to comment prior to excluding Green Zone land from the ALR) ([66], p. 1).

On 17 September 2003 a Staff Report Supplement was prepared, providing the Commission with additional information on the day of the scheduled meeting to consider the exclusion [72]. The staff report supplement admitted that the District of Maple Ridge's park designation for the property precluded Maple Ridge's intent to preserve the property for farming, except perhaps for heritage demonstration purposes. The supplemental report therefore recommended the property be excluded from the ALR, which is what the ALC Land Commissioners proceeded to do. Most interesting to note about the decision making process in this case is that despite staff recommendations in the first staff report, no formal written correspondence was received from Metro Vancouver prior to the decision. In fact, the only attempt to gain formal written correspondence from Metro Vancouver regarding the exclusion occurred on 17 September 2003, the day of the decision [73]. The memorandum in response to the request was prepared by Metro Vancouver the day after, 18 September 2003, and indicated that the property was in fact "within the area designated by the District of Maple Ridge as Green Zone in the LRSP" ([73], p. 1).

Specifically, this Metro Vancouver memorandum reiterated the fact that the District of Maple Ridge placed the Jackson Farm outside of the urbanized areas listed in its OCP, while stating in its regional 
context statement, the importance of protecting the Green Zone and limiting urban areas to within the proposed containment boundaries. Furthermore, Metro Vancouver noted that the District of Maple Ridge's regional context statement recognized Green Zone lands, such as Lower Jackson Farm, "through land use designations as being protected for their natural resource values," while additionally stating the importance of "promoting the viability of agriculture through public policy" ([73], p. 2). The memorandum concluded that removing Lower Jackson Farm from the ALR and Green Zone would be inconsistent with the District's OCP and regional context statement, and would compromise Green Zone objectives.

The ALC and Metro Vancouver had a LRSP Implementation Agreement in place, dedicated to "supporting agriculture in Greater Vancouver and the LRSP" ([74], p. 1). The agreement said that the ALC should "refer to the GVRD Board for comment any changes to the Agricultural Land Reserve boundaries within or adjacent to the Greater Vancouver Regional District that would have a significant impact on the LRSP” ([74], pp. 4, 5). This Implementation Agreement did not legally require compliance, but rather formed a special partnership between the two government agencies. Person $\mathrm{X}$ of the ALC identified that "the Commission believed that the land was in fact affected by the Green Zone; however [the ALC was] verbally advised by Metro Vancouver that it was not affected by the Green Zone." The ALC nevertheless sent the written request as a formality on the day of its decision, only to learn "after the decision had been made...that in fact Metro Vancouver wished to express its opposition" (Person X of the ALC). It seems that a series of unfortunate events occurred that may have drastically influenced both ALC staff position on the application, and possibly the end decision of the Land Commissioners.

\subsection{Lower Jackson Farm: Green Zone Amendment Application}

The District of Maple Ridge claimed that Lower Jackson Farm's inclusion in the Green Zone was a "mapping error," with the evidence being that, according to Person Y of the District of Maple Ridge, the 1996 plan did not specifically name Jackson Farm as a park, as it did other parks. Any intentional exclusion of Lower Jackson Farm from the Green Zone, however, would have made Maple Ridge noncompliant with the LRSP. This is because failing to include it would have dismissed the fact that Lower Jackson Farm automatically qualified for inclusion based on its ALR status at that time, based on the Guidelines for Identifying Green Zone Lands [75]. Both parties agreed that it was best to assume it was in the Green Zone, in order to ensure this policy dispute underwent proper review. The result was that the development application on Lower Jackson Farm was deemed to require a Green Zone amendment involving a regional public hearing. In the interim, the District re-designated Lower Jackson Farm from Park to Agricultural [67].

The Lower Jackson Farm proposal became part of a larger application to convert a total of 33.09 hectares of protected lands within the District of Maple Ridge to urban uses, including eleven properties at six different locations referred to as the Starred Properties (Figure 6) [76]. In July 2006, Maple Ridge formally requested that Metro Vancouver consider removing the properties from the Green Zone; the only way to do this was to amend the LRSP, requiring a $100 \%$ vote from Metro Vancouver board members [76]. 
Following a decision to defer Maple Ridge's proposed amendments to the Green Zone, on 22 November 2007, under the statutory authority of Section 799 of the Local Government Act [77], the provincial government passed Order in Council 768 to create the Greater Vancouver Regional District Regional Growth Strategy Exemption Regulation [78]. The Exemption Regulation was specifically passed by the provincial government to allow Metro Vancouver to amend designations under strict circumstances: "only if...in the opinion of the board, the amendment is consistent with protecting Greater Vancouver's natural assets, including major parks, watersheds, ecologically important areas and farmlands, as set out in the LRSP" [77]. Finally, in order to pass an amendment to the Green Zone, the Exemption Regulation stipulated under Section 3 (3) (b) that the land use designation amending bylaw be "adopted by at least two thirds of the votes cast," by the Board of Metro Vancouver [77].

Figure 6. Map of Starred Properties (District of Maple Ridge), under consideration for LRSP Green Zone (Amendments; with Site \#6 being Lower Jackson Farm. Source: Metro Vancouver, 2008, adapted with permission).

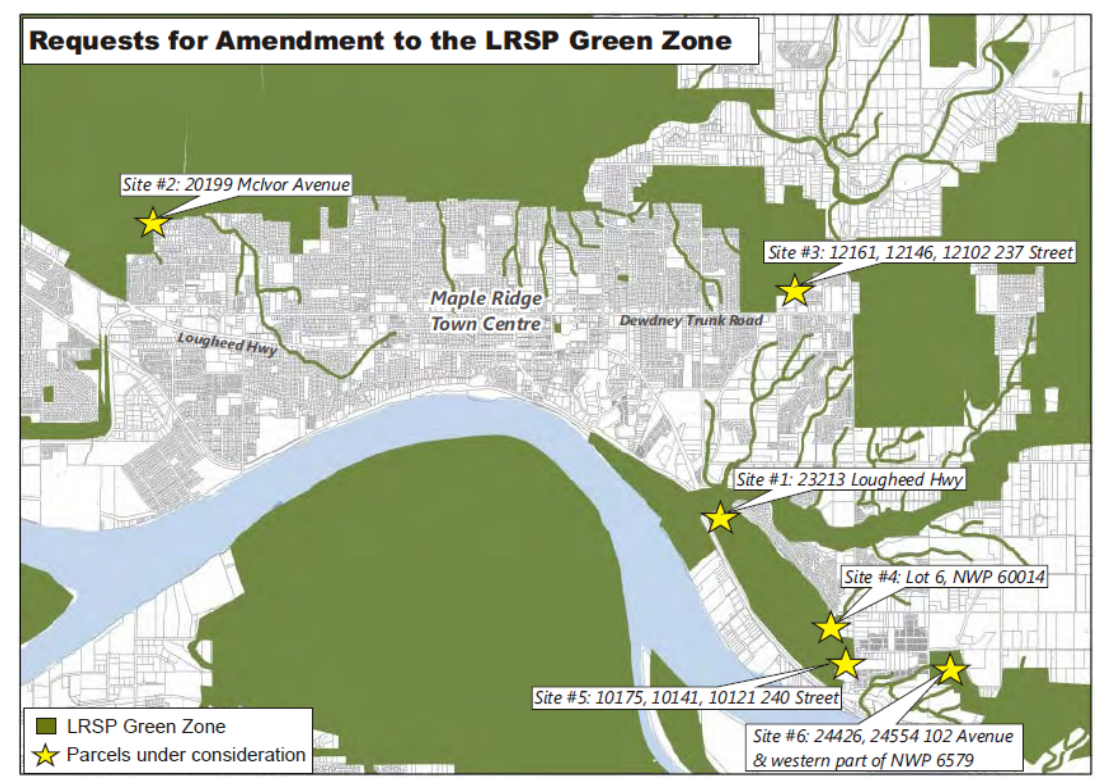

Person $\mathrm{Z}$ of Metro Vancouver noted that this was a "really important part of history in regional planning." The amendment process established a $66 \%$ vote threshold at the regional board to approve changes to the Green Zone. While the Regional District did believe this amendment process was necessary, there were nevertheless also several major developers in the region who were pushing the Province to do this. The $66 \%$ threshold was seen as sufficient to ensure LRSP "relevance" while still allowing the Regional District to "maintain the integrity of the strategy".

Upon these new legislative grounds, Metro Vancouver prepared a staff report, dated 18 June 2008, to provide the Metro Vancouver Board with information pertaining to the exclusion application for the six subject sites to be re-designated as urban areas. The Green Zone designation affected $73 \%$ of Maple Ridge's land base, and in the opinion of Metro Vancouver those properties included in the starred sites were within this designation because of agricultural merits, though all had since been excluded from the ALR or exempt from its regulations due to their small size [76]. Metro Vancouver 
staff recommendations pertaining to sites \#1, \#2, \#3, \#4, and \#5 were to support the Green Zone amendments, given that the applications were "consistent with the criteria outlined in the ... Regional Growth Strategy Exemption Regulation and the objectives of the LRSP” ([76], p. RD-27).

Metro Vancouver staff recommended that the request to remove site 6 (Lower Jackson Farm) from the Green Zone be denied, because they found the proposal to remove it in conflict with the LRSP [76]. They concluded that "Jackson Farm's natural assets are of importance to the Green Zone because of the site's size, connectivity to existing undeveloped and other Green Zone areas, and site ecological and cultural values" ([76], p. RD-26). Specifically, it was felt that Lower Jackson Farm served as a critical Green Zone link between Kanaka Creek Regional Park and the Fraser River [76].

While the initial ALR exclusion application only resulted in five letters of opposition and a forty-one member petition, in March 2007, a 3000 member petition was submitted in opposition to the related Green Zone amendment, requesting that the Jackson Farm be considered for a neighbourhood park and noting that the removal of the lands from the ALR was unacceptable and contrary to past agreements [76]. Jackson Farm's proposed development also sparked citizen concern that resulted in the formation of its own "grass roots citizen group called Friends of the Jackson Farm" ([76], p. RD-105). In a presentation this group gave at the Metro Vancouver Board of Directors meeting on 18 July 2008, they highlighted that the owners of Jackson Farm were continuing to pay farm taxes on the property and harvest hay each year, while at the same time going through exclusion applications claiming that the property should be developed rather than used as a farm [79].

During the public hearing, twenty-eight speakers gave presentations to the Board of Metro Vancouver over more than two hours [80]. Eighteen speakers spoke in opposition to the Green Zone amendment for Jackson Farm, including all three Maple Ridge Councilors who had opposed the application at the municipal hearings in the 4:3 vote. Of the nine who spoke in favour, five had financial stakes or spoke on behalf of those who had financial stakes in the properties. At this time, the Board asked several questions. Responses given outlined the fact that the Jackson Farm did have the potential to be utilized as a future passive park area; however, the District of Maple Ridge had other higher priorities for parkland acquisition and as such their Parks Master Plan recommended that the site be allowed to be acquired for other uses [81].

Following receipt of further requested information from planning staff at the GVRD Board of Directors 24 October 2008 meeting, all six bylaws for the Starred Properties were considered for Green Zone amendments. Approval motions for sites \#1 and \#2 were unanimous; sites \#3, \#4, and \#5 were also approved, with some Board members opposed [82]. The Board defeated Bylaw No. 1093 to amend Lower Jackson Farm from the Green Zone; with the following reasons given:

- It is actively farmed land.

- $56 \%$ of the property will not be donated as a park as indicated by the developer but will be required by the District of Maple Ridge to be preserved as an Environmentally Sensitive Area.

- The development will have a negative impact on adjacent parkland, agricultural land and the Fraser River.

- Removal of the property would set a precedent for development in the area.

- To overcome world food crisis, all remaining agricultural land needs to be preserved ([82], pp. 12, 13). 


\subsection{Lower Jackson Farm for Upper Jackson Farm}

Following the Metro Vancouver decision, in late 2008 the owners of Jackson Farm utilized existing property rights to make subdivision applications on Lower and Upper Jackson Farm. This involved carving the 15.07 hectare Lower Jackson Farm parcel into seven lots, and the 8.96 hectare Upper Jackson Farm parcel into four lots, in keeping with all existing Green Zone, OCP and zoning restrictions [67]. Subsequently, the owners of the Jackson Farm approached various members of Maple Ridge's Council and met with staff to discuss alternate development options for the farm that would compensate for the loss in lot yield that resulted from Metro Vancouver denying the requested Green Zone amendment [67]. Although permitted a maximum of four lots on Upper Jackson Farm, the owners proposed advance development rights to allow for 113 residential lots on the parcel in exchange for dedicating Lower Jackson Farm to the District as a park, while negating all required development milestones and detailed reports that were stipulated within the OCP [67].

Following review, Maple Ridge staff determined that "acquiring Jackson Farm through the advancement of development on a parcel of land currently within the Urban Reserve [was] not supported" ([67], p. 12). Staff informed Council that the proposal made by the owner of the Jackson Farm would "require numerous amendments to the OCP, [and] the regional context statement," as well as raise "questions about development on both neighbouring properties and the Urban Reserve itself" ([67], p. 12). They further informed Council that many residents in the community wished to see Lower Jackson Farm preserved as a municipal park; noting that funding mechanisms to achieve this desired outcome had not yet been explored in detail. There were viable options other than the one proposed by the owners of the Jackson Farm [67].

According to Person Y of the District of Maple Ridge, staff made it very clear to Council that in their professional opinion it was not a good idea to shift the boundary of the Thornhill Urban Reserve in order to permit development. After consideration of the staff report, on 14 April 2009 District of Maple Ridge Council passed a resolution to direct staff to proceed with the property owners' proposal [83]. Following this decision, an agreement was reached between the District and the developer that involved revising the proposed lot yield from 113 to 112, dedicating Lower Jackson Farm as a park, dedicating environmentally sensitive areas on Upper Jackson, and providing minimum $4.0 \mathrm{~m}$ and $11.0 \mathrm{~m}$ landscape buffer strips along 248th Street and 100th Avenue to buffer the development on Upper Jackson from non-urban uses.

An 11 February 2010 Metro Vancouver staff report highlighted the most pertinent planning issues in order for the Board to make a decision on the proposed development of Upper Jackson Farm in exchange for Lower Jackson Farm being dedicated as a park. It finished with a lengthy conclusion for the Board of Metro Vancouver to consider, which stated:

This is not an easy decision, particularly in the context of attempting to establish a new more effective regional growth strategy (The update to the Livable Region Strategic Plan, the Regional Growth Strategy, passed in July 2011). While there is broad acceptance of the need to achieve an appropriate balance between regional and local interests and authority, there is still a sentiment expressed in some quarters that, contrary to legislation, municipal autonomy should prevail. In an attempt to address those views, regional staff has taken considerable pains to stress that the Regional Context Statement acceptance process has and will allow significant latitude for local 
variations to be accepted where they do not undermine the fundamental goals and principles of the plan. This particular proposal may well be seen as a test of that proposition.

The Maple Ridge regional context statement for Thornhill sets out sound planning principles, reflecting the principles of the regional growth strategy, and which should not be set aside lightly. If this decision were to be taken as a precedent for the rest of Thornhill, the concerns would be profound. A further difficulty arises from the fact that there appear to be alternative strategies available that may have been acceptable to the owner which would not have necessitated the compromising of the Thornhill Urban Reserve policies. A land swap for lands already within the area designated for development would have been a particularly happy solution. As the published documents do not provide any analysis of these alternatives, regional staff contacted Maple Ridge staff to determine if they had indeed been investigated. Those assurances were provided and it appears the complexities involved particularly in achieving a value for value exchange, eventually were too discouraging for the property owners to proceed.

Consequently, notwithstanding the real planning concerns that have been raised, it seems reasonable to conclude that the proposal to secure the Lower Jackson Farm by transferring development rights to the Upper Jackson Farm is the most practical method of achieving an outcome of considerable local importance and one which the Board has previously found to be of regional interest. The planning implications are uncomfortable at both the local and regional level and it is unlikely that complete consensus about the decision would be found at any level, staff, elected officials or the community. Nonetheless, looking at the balance of interests which is the critical concept being promoted, the importance of the outcome achieved, the efforts made by the local authority to find an acceptable solution, and the limited regional impact if this is not viewed as a precedent, lead to the conclusion and recommendation that the proposed amendment be accepted ([84], p. 6).

On 4 March 2010, the Board approved the regional context statement amendment for Maple Ridge. On one hand it was important that Metro Vancouver explicitly noted that they would not allow this to be a precedent setting decision for Thornhill, but on the other hand it seems that another precedent was set by Metro Vancouver entertaining a "value for value exchange" in this case that involved compromising regional planning objectives. In other words, while Metro Vancouver made it clear that the Upper Jackson Farm decision would not be a precedent for development on Thornhill, they did set a precedent that a regional planning objective can be dismissed if it involves a compromise that allows the achievement of some other regional planning objective deemed to be more significant.

Shortly after this decision was made by Metro Vancouver, controversial donations to some Maple Ridge Councilors during the 2008 election campaigns were exposed [85]. These campaign donations originated from a company owned by the Jackson Farm developer and their consultant, and involved three members of Council: Mayor Daykin and Councilors Dueck and Hogart. Councilors Speirs and King continued to oppose the application, while Councilor Gordon who had previously been opposed was not re-elected in 2008. Given the 5-2 Council vote to support development on Upper Jackson Farm, campaign donations to three of five councilors who voted in favour of the proposal raises questions regarding the impartiality of Maple Ridge politicians fulfilling their duty to make decisions for the public good. 


\section{Discussion}

Whether or not the controversial donations that were associated with the Jackson Farm caused unethical political conduct is not what makes this case unique. Campaign donations by private interests are part of the political reality of municipal politics in Metro Vancouver; and as stated earlier, escalation in urban land values in Vancouver makes a strict economic case for agricultural land preservation untenable. Consequently, short of a significant overhaul of election processes, associated campaign funding practices, and urban land economics, these will remain overarching hurdles for sustainable development policy, here as elsewhere.

The question of the best scale for agricultural protection and urban containment policy and planning has been hotly debated in Canada and the U.S. in particular, challenged by questions of local autonomy and expectations of jurisdiction, the drive to develop, key stakeholders, power brokers, and differential access to decision makers at the various scales. In this case, local, regional, and provincial government policy played a role in competing expectations for sustainable development outcomes, and differential ability to implement policy at the three levels played a role in the outcomes achieved. In some respects, the circuitous course of implementation in this case served the public interest: while the local government officials ignored staff recommendations, and the ALC consented to the proposal, the regional government demanded a different outcome, following more review. With more time in review, public awareness of the development application grew, which enabled concerned members of the public to mount a sustained campaign. In a different case, perhaps the balance of interests would be juggled differently by the different actors involved; and uncertainty regarding who has the authority to make the final decision is perhaps not always a negative situation for sustainability outcomes. What this case additionally makes clear, however, is that the multigovernance and collaborative nature of the policy process in Metro Vancouver presents limits as well as opportunities to agricultural land preservation outcomes, in which the demands of ecological modernization — a "win-win" or "value for value" exchange - appear to take precedence over the pre-existing arguments in favour of agricultural land protection. To this end, the Jackson Farm case ultimately serves as a disconcerting but necessary reminder that effective sustainable development policy must withstand myriad challenges of implementation and compromise-seeking from different perspectives. In this case, the balance sheet reads: compromised local area, community and regional plans; loss to the agricultural land base; intensified urban development on the suburban fringe; a parkland donation; promises that this would be an exception rather than a new precedent (and perhaps some money for political campaigns to boot).

Caulfield theorized that "local authority control over planning and land-use decisions ... [is] largely developer-driven," with the "net effect [being] that developers, rather than plans, [drive] the decision-making process" ([45], pp. 435, 436). The fact that the majority of Maple Ridge Council supported the developer preferred option for Jackson Farm, despite staff opinion advising against it, supports this theory in this case. However, given Metro Vancouver's intervention and resultant decision to compromise, this does not represent the whole story. The Jackson Farm case highlights the frayed nature of the consensus-based regional planning culture in the face of the struggle to maintain municipal autonomy, which may be tantamount to undermining regional sustainable development policies related to agricultural land protection by supporting competing objectives instead. 
While the Jackson Farm case demonstrates an appetite in Metro Vancouver to attain sustainable development policy objectives, it also demonstrates an appetite for finding compromises that result in some sustainability objectives being met, while conceding others to private development interests, often in the guise of "win-win" —or at least "value for value"-trade-offs between environmental and economic interests [48]. This supports the interpretation of sustainable development policy implementation in Metro Vancouver as pursuing an ecological modernization agenda [47]. In this context of constant consideration of trade-offs, determining how much agricultural land is enough is an elusive task, a characterization Scott Campbell [86] gave to the work of determining the correct balance of environmental, social and economic factors for sustainable city planning. In this way, the Jackson Farm case resulted in a sustainable development compromise whereby all sides accepted less than what they originally wanted. Such a policy solution could also be seen as sustainable development compromised; meaning the policies themselves and theories behind what constitutes sustainable development are sacrificed by the dilution of adopted policy objectives during plan implementation. While such an outcome is not the worst case scenario, it nevertheless tips the balance of policy objectives towards short term economic benefits for the few at the sacrifice of long term environmental and social justice for the greater public good.

The possibility of a shifting planning culture demonstrated by this case underscores the conclusion of Frenkel and Orenstein [87] with regard to the necessary link between agricultural land protection policy and local context. In the case they studied in Israel, early agricultural land protection policy in the 1990s, under a similar social democratic government regime to that which established the ALC in BC in the 1970s, "was successful in meeting growth management goals primarily because of the socioeconomic and political context of the time [marked by] significantly lower economic prosperity and less market pressure for development" ([87], p. 30). Despite the physical constraints of the Metro Vancouver region which ultimately present limits to urban sprawl, the ALR and the Green Zone are valuable only to the extent that they retain the social license for implementation with which they were originally created. Where this social license or planning culture slips into a different socioeconomic context, pressures upon governments to compromise will build up in specific places, contributing over time to long-term trends and effects that lead us far astray from the goals we once agreed to.

The new Regional Growth Strategy, which replaces the LRSP, divides the Green Zone into Agricultural, Rural, and Recreation and Conservation designations. This move increases the importance of the distinction between agricultural potential and agricultural use in land use designations. The means by which human civilizations have maintained food security has continually and dramatically changed throughout our modern history, such that assuming that today's methods of agricultural production will continue into the future would represent a carelessly weak sustainability stance. As such, proactive policies are needed within the ALC that support collaboration with Metro Vancouver, and other regional districts alike, to forecast the potential agricultural needs of future generations and protect all lands with agricultural merit.

Our analysis of the Jackson Farm case also suggests a path to improve implementation such that ALR exclusion applications and amendments to land use designations may be better procedurally linked. Running applications concurrently could foster a high degree of inter-governmental coordination. Nevertheless, doing so should not involve a complete merging of the applications, as the 
Jackson Farm experience clearly indicates that, although imperfect, a "safety net" exists when each governmental body makes its own decision.

A potential revised application processing model for ALR exclusions in Metro Vancouver could involve both the ALC and Metro Vancouver receiving the application proposal at the same time (Figure 7). Both government agencies would thus simultaneously conduct a separate review of the application based on institutionally specific mandates. Following this, ALC and Metro Vancouver staff would come together with their own memorandum containing their recommendations on the case. At this point, ALC and Metro Vancouver staff would make a joint recommendation. The application would then be brought forward to a Metro Vancouver Public Hearing, where the public would be given an opportunity to voice opinions on the proposal. Following the Public Hearing, both the Board of Metro Vancouver and the ALC would make their own decisions based on each agency's objectives and input received from the public. If both the Commission and the Board of Metro Vancouver separately agreed to approval at this point, then both governing bodies would amend their designations of the subject lands accordingly. If either governmental body disagreed with the proposal at this point, then both would decline the application in order to maintain policy consistency. Such a process would establish a precautionary principle in relation to agricultural land use management and maintain policy consistency between the ALC and Metro Vancouver. Other possible principles by which to keep score of the "winners" and "losers" in compromise decisions may be found by linking sustainability policy more closely to environmental economics theory [88].

Figure 7. Proposed application process flow chart (Source: Jonathan Jackson, 2012).

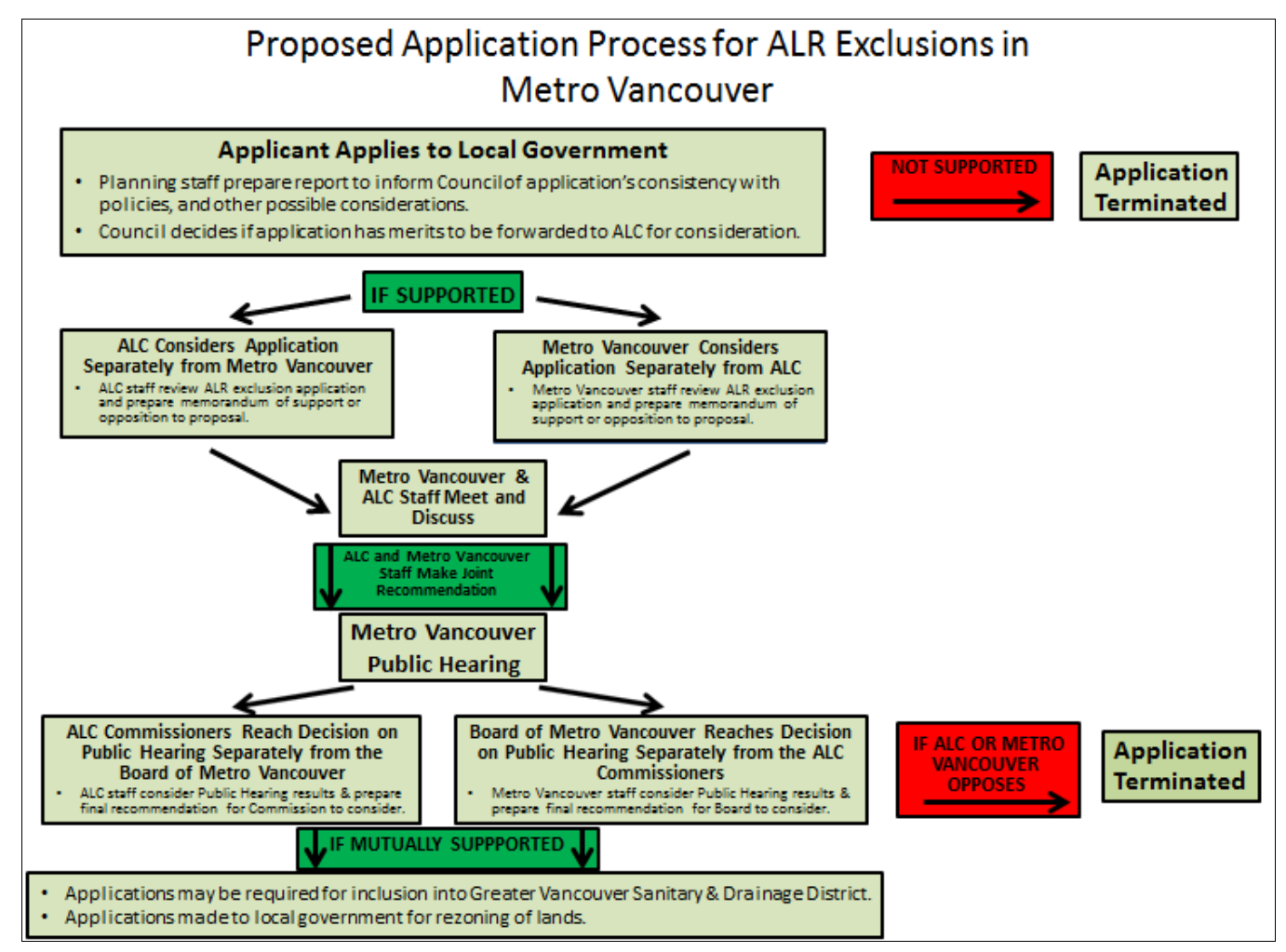

The future of agriculture in many urbanizing regions worldwide is under threat, due to sprawl, encroachment, and the demands of capital. As urban land values increase, it becomes less and less viable to advance an economic rationale for the preservation of agricultural land in regions like 
Vancouver. Currently, in BC, the ALC and ALR system are in the additionally difficult position of having to justify the public funds allocated to them, as the province undertakes a "core review" with a view to seeking cost savings [89]. The District of Maple Ridge, for its part, views the mandate of this review as "risky business" [90].

From the origins of the Agricultural Land Commission in 1972 to the language of the 2008 Metro Vancouver decision to keep Lower Jackson Farm within the Green Zone as part of the task "to overcome world food crisis" the policy stance regarding agricultural land preservation has been driven by a rationale not of maximizing economic gain or even balancing urban and rural development priorities in line with the interests of the electorate. The viability of agricultural land within the region is key to food security and sovereignty, and thus has a measure of primacy above urban land uses [91]. Although technological efficiencies of the agro-industrial food system have lessened current agricultural demand for arable lands in Metro Vancouver, this may not be sustainable in the long term. If we are to consider the Cuban precedent presented by Wright [32], localized food production within the region may well be the way of the future, just as it was the way of Metro Vancouver's past. As such, parcels such as Jackson Farm, although perhaps not currently demanded for agriculture may well again become critical for maintaining food security; this underlines the obligation of the Province to mandate the ALC as line of defense against the erosion of potentially productive farmland in the region to ensure capacity in food sovereignty.

In light of this plausible future, the Commission would do well to seek additional public consent for the need to exercise a food security and sovereignty agenda that sees no exception to preserving arable land that has agricultural merits as part of the regional stock of critical natural capital; even if such merits are not currently being utilized. Such a model for farmland protection could see a return to the Commission's early days of proactively seeking to add new lands to the ALR. This could ideally see tracts of parkland in densely populated urban areas as having potential agricultural benefits, making them candidates for absorption into the ALR to ensure that interim uses do not compromise their future food producing capabilities. Metro Vancouver perceived Lower Jackson Farm as having important merits both as a park and as farmland, which clearly indicated policy direction suggesting that park uses do not have to preclude farm uses.

\section{Conclusions}

While the Jackson Farm case may not have resulted in the best possible outcome, it is nevertheless likely that the compromises to sustainable development would have been significantly worse, had it not been for the efforts of planning staff, community members, some local and many regional politicians that recognized the importance of Jackson Farm and fought for its protection. Nevertheless, outcomes of the Jackson Farm case, resulting in a dilution of one policy objective to uphold another, elucidate the need to question whether sustainable development compromises in fact compromise sustainable development overall; and whether agriculture continues to demand treatment as a critical regional resource, as was the policy consensus when the ALR was established in 1972. From a planning perspective, the case reveals the implementation challenges that confound the execution of even strong policy and planning structures. 
The Jackson Farm case serves as a reminder that Metro Vancouver is subject to similar trends as seen in other regions, where competing jurisdictions, politics and influential private interests can undermine agricultural land use planning policies. At a regional level, some of these obstacles of implementation could be overcome by improvements to coordination and specified roles for municipalities and regional planning bodies, in the context of struggles for municipal autonomy by member municipalities. The Jackson Farm case also serves as reminder of the imperfect but important safety net created by the redundancy in jurisdiction between the ALC and Metro Vancouver over the protection of farmland. As such, while it seems practical to investigate ways to improve application processing on proposals that require approval from multiple government bodies, Jackson Farm demonstrates the importance that any changes to this process not compromise the decision making safety net that currently exists by having both government agencies make independent determinations on a given case based on their separate mandates.

While the authority of the ALC has been contested by various political regimes since its inception, the success of the farmland protection policy in its early years has allowed it to survive the rulings of governments from opposite ends of the political spectrum [50,51]. Despite occasional challenges to the legislative authority of the ALC, the ALR, along with its multijurisdictional collaborative implementation process, has become renowned as a successful, if not a revolutionary, urban containment boundary and guardian of farmland; surpassing other North American models of agricultural land protection [58]. Even so, the Jackson Farm case suggests that the ALC's mandate could be enhanced by considering the potential need of future generations to have much more localized agriculture that does not rely significantly on petroleum inputs. At any rate, a renewal of the planning culture put in place via the establishment of the ALC and LRSP, is needed if the implementation of agricultural protection is to proceed in line with its original intent in the contested practice of urban development in the Metro Vancouver region.

In closing, it seems worth highlighting that although the findings of this research are useful to provide insight into areas of policy in need of improvement and possible future directions for farmland protection in Metro Vancouver, it is important to note that these issues are shared with other regions and the solutions to reworking farmland protection land use policy, and the way it is implemented, may be transferable. Nevertheless, the ultimate and potentially daunting challenge remaining for planners and academics is to harness political will to support and implement strengthened sustainable development policy.

\section{Acknowledgments}

We would like to thank the government representatives from the District of Maple Ridge, Metro Vancouver, and the Agricultural Land Commission who shared interview data to provide supporting details that were critical to this research.

\section{Conflicts of Interest}

The authors declare no conflict of interest. 


\section{References}

1. Northwest Environment Watch. Sprawl and Smart Growth in Greater Vancouver: A Comparison of Vancouver, British Columbia, with Seattle, Washington; Sightline Institute: Seattle, WA, USA, 2002.

2. Cameron, K.; Harcourt, M.; Rossiter, S. City Making in Paradise; Douglas \& McIntyre: Toronto, ON, Canada, 2007.

3. Brugmann, J. Welcome to the Urban Revolution; Bloomsbury Press: New York, NY, USA, 2009.

4. Fox, D. Halting urban sprawl: Smart growth in Vancouver and Seattle. Boston College Int. Comp. Law Rev. 2010, 33, 43-59.

5. Northwest Environment Watch. The Portland Exception: A Comparison of Sprawl, Smart Growth, and Rural Land Loss in 15 US Cities; Sightline Institute: Seattle, WA, USA, 2004.

6. Bengs, C.; Schmidt-Thomé, K. Urban-Rural Relations in Europe. Available online: http://www.espon.edu (accessed on 25 June 2013).

7. Abbott, C.; Margheim, J. Imaging Portland's urban growth boundary: Planning regulation as cultural icon. JAPA 2008, 74, 196-208.

8. Abrantes, P.; Marques da Costa, E.; Padeiro, M.; Queiros, M. Agriculture and Urban Sprawl in the Lisbon Region: What Visions for Agriculture in Spatial Planning Documents? In Proceedings of the AESOP-ACSP Congress, Dublin, Ireland, 15-19 July 2013.

9. Adler, S. The Planning History, Theory and Politics of the Portland Metorpolitan Area's Original Urban Growth Boundary. In Proceedings of the AESOP-ACSP Congress, Dublin, Ireland, 15-19 July 2013.

10. Wilson, B.; Song, Y. Comparing apples with apples: How different are recent residential development patterns in Portland and Charlotte? J. Urban. 2009, 2, 51-74.

11. Taylor, Z.; Burchfield, M. Growing Cities: Comparing Urban Growth Patterns and Regional Growth Policies in Calgary, Toronto, and Vancouver; Neptis Foundation: Toronto, ON, Canada, 2010.

12. Bula, F. Home in the Suburbs, Heart in the City. Available online: http:/www.theglobeandmail.com/ news/british-columbia/home-in-the-suburbs-heart-in-the-city/article585820/ (accessed on 25 June 2013).

13. Zinn, J. Residents Fight Application to Remove Land from ALR. Available online: http://www.thenownewspaper.com/Residents+fight+application+remove+land+from/8723612.html (accessed on 25 June 2013).

14. Nagel, J. Metro Vancouver Takes Langley Township to Court over Growth Plan. Available online: http://www.langleytimes.com/news/215598621.html (accessed on 25 June 2013).

15. Marshall, C.; Rossman, G. Designing Qualitative Research; SAGE Publications Ltd.: London, UK, 1995.

16. Hirschmann, A.O. A Bias for Hope: Essays on Development and Latin America; Westview Press: Boulder, CO, USA, 1985.

17. Yin, R.K. Case Study Research; SAGE Publications Ltd.: London, UK, 1984.

18. Sjoberg, G.; Williams, N.; Vaughan, T.R.; Sjoberg, A.F. The Case Study Approach in Social Research: Basic Methodological Issues. In A Case for the Case Study; Feagin, J.R., Orum, A.M., Sjoberg, G., Eds.; University of North Carolina Press: Chapel Hill, NC, USA, 1991; pp. 27-79. 
19. Orum, A.M.; Feagin, J.R.; Sjoberg, G. Introduction: The Nature of the Case Study. In A Case for the Case Study; Feagin, J.R., Orum, A.M., Sjoberg, G., Eds.; University of North Carolina Press: Chapel Hill, NC, USA, 1991; pp. 1-26.

20. Weiss, C. Evaluation, 2nd ed.; Prentice Hall: Englewood Cliffs, NJ, USA, 1998.

21. Snow, D.A.; Anderson, L. Researching the Homeless. In A Case for the Case Study; Feagin, J.R., Orum, A.M., Sjoberg, G., Eds.; University of North Carolina Press: Chapel Hill, NC, USA, 1991; pp. 148-173.

22. Bennett, C.; Howlett, M. The lessons of learning: Reconciling theories of policy learning and policy change. Policy Sci. 1992, 25, 275-294.

23. Flyvbjerg, B. Making Social Science Matter; Cambridge University Press: Cambridge, UK, 2001.

24. Orum, A.M.; Feagin, J.R. A Tale of Two Cases. In A Case for the Case Study; Feagin, J.R., Orum, A.M., Sjoberg, G., Eds.; University of North Carolina Press: Chapel Hill, NC, USA, 1991; pp. 121-147.

25. Loftland, J.; Loftland, L. Analyzing Social Settings; Wadsworth Publishing Company: Belmont, CA, USA, 1994.

26. Sayer, A. Method in Social Science, 2nd ed.; Routledge: New York, NY, USA, 2010.

27. Ragin, C., Becker, H., Eds. What Is A Case? Exploring the Foundations of Social Inquiry; Cambridge University Press: Cambridge, UK, 1992.

28. Agriculture and Agri-Food Canada (AAFC). Canada's Action Plan for food Security: A Response to the World Food Summit; AAFC: Ottawa, ON, Canada, 1998.

29. Huish, R. Human security and food security in geographical study: Pragmatic concepts or elusive theory? Geogr. Compass 2008, 2, 1386-1403.

30. Bristow, D.; Kennedy, C. Urban metabolism and the energy stored in cities. J. Ind. Ecol. 2013, 17, 656-667.

31. Windfuhr, M.; Jonsén, J.; Food Sovereignty: Towards Democracy in Localized Food Systems; Intermediate Technology Development Group (ITDG): Rugby, UK, 2005.

32. Wright, J. Sustainable Agriculture and Food Security in an Era of Oil Scarcity: Lessons from Cuba; Earthscan: London, UK, 2009.

33. Dalichow, F. Agricultural Geography of British Columbia; Versatile Publishing Co. Ltd.: Vancouver, BC, Canada, 1972.

34. Ministry of Agriculture and Lands. B.C.'s Food Self-Reliance: Can B.C.'s farmers Feed Our Growing Population? B.C. City of Vancouver: Vancouver, BC, Canada, 2006.

35. Bartlett, A.A. Reflections on sustainability, population growth, and the environment. Popul. Environ. 1994, 16, 21-28.

36. Boone, C.G.; Modarres, A. City and Environment; Temple University Press: Philadelphia, PA, USA, 2006.

37. Kendall, H.W.; Pimentel, D. Constraints on the expansion of the global food supply. Ambio 1994, 23, 198-205.

38. Suzuki, D. The Sacred Balance: Rediscovering Our Place in Nature; Greystone Books: Vancouver, BC, Canada, 2007.

39. Haber, W. Energy, food, and land - the ecological trap of humankind. Environ. Sci. Pollut. Res. 2007, 14, 359-365. 
40. Jaeger, J.A.G.; Bertiller, R.; Schwick, S.; Kienast, F. Suitability criteria for measures of urban sprawl. Ecol. Indic. 2009, 10, 397-406.

41. Berke, P.R.; Manta Conroy, M. Are we planning for sustainable development? J. Am. Plan. Assoc. 2000, 66, 21-33.

42. Berke, P.R. Does sustainable development offer a new direction for planning? Challenges for the twenty-first century. J. Plan. Lit. 2002, 17, 21-35.

43. Newman, P.; Jennings, I. Cities as Sustainable Ecosystems: Principles and Practices; Island Press: Washington, DC, USA, 2008.

44. Stone, D. Policy Paradox: The Art of Political Decision Making; Norton: New York, NY, USA, 2002.

45. Caulfield, J. Responses to growth in the Sun-Belt State: Planning and coordinating policy initiatives in Queensland. Aust. J. Public Adm. 1993, 52, 431-442.

46. Williams, K. Urban intensification policies in England: Problems and contradictions. Land Use Policy 1999, 16, 167-178.

47. Hajer, M. The Politics of Environmental Discourse: Ecological Modernization and the Policy Process; Oxford University Press: Oxford, UK, 1995.

48. Batty, S.E. Planning for sustainable development in Britain: A pragmatic approach. Town Plan. Rev. 2006, 77, 29-40.

49. Mäler, K. Wealth and sustainable development: The role of David Pearce. Environ. Res. Econ. 2007, 37, 63-75.

50. Garrish, C. Unscrambling the omelette: Understanding British Columbia's agricultural land reserve. BC Stud. 2002, 136, 25-55.

51. Yearwood-Lee, E. History of the Agricultural Land Reserve; Legislative Library of British Columbia: Victoria, BC, Canada, 2008; pp. 1-14.

52. Provincial Agricultural Land Commission. About the Agricultural Land Reserve. Available online: http://www.alc.gov.bc.ca/alr/ (accessed on 25 June 2013).

53. Hodge, G.; Robinson, I.M. Planning Canadian Regions; UBC Press: Vancouver, BC, Canada, 2001.

54. Tomalty, R. Growth management in the Vancouver Region. Local Environ. 2002, 7, 431-445.

55. Smith, P.J.; Oberlander, P.H. Greater Vancouver: L'exception Canadienne Metropolitaine. In Metropolitan Governing: Canadian Cases, Comparative Lessons; Razin, E., Smith, P.J., Eds.; The Hebrew University Magnes Press: Jerusalem, Israel, 2006; pp. 147-183.

56. Rothblatt, D.N. North American metropolitan planning: Canadian and U.S. perspectives. J. Am. Plan. Assoc. 1994, 60, 501-520.

57. Leo, C.; Anderson, K. Being realistic about urban growth. J. Urban Aff. 2006, 28, 169-189.

58. Smart Growth BC. Smart Growth BC's Position on the Provincial Agricultural Land Reserve (ALR). Available online: http://www.smartgrowth.bc.ca/Portals/0/Downloads/ SGBCALRposition.PDF (accessed on 25 June 2013).

59. Oberlander, P.; Smith, P. Governing Metopolitan Vancouver: Regional Intergovernmental Relations in British Columbia. In Metropolitan Governance: American/Canadian Intergovernmental Perspectives; Rothblatt, D.N., Sancton, A., Eds.; Institute of Governmental Studies Press: Berkeley, CA, USA, 1993.

60. Campbell, C. Forever Farmland: Reshaping the Agricultural Land Reserve for the 21st Century; David Suzuki foundation: Vancouver, BC, Canada, 2006. 
61. District of Maple Ridge Official. History and Heritage. Available online: http://www.mapleridge.org/ EN/main/residents/569/history.html (accessed on 25 June 2013).

62. Friends of the Jackson Farm. Available online: http://jacksoncommon.org/ (accessed on 25 June 2013).

63. Luxton, D. The Heritage Resources of Maple Ridge. Available online: http://www.mapleridge.ca/ assets/Default/Clerks/Committees $\sim$ and $\sim$ Commissions/Community $\sim$ Heritage $\sim$ Commission/Heritage Inventory/pdfs/7.albion.pdf\#search=\%22Jackson $\% 20$ Farm $\% 20$ Heritage $\% 22$ (accessed on 25 June 2013).

64. Maple Ridge Museum and Community Archives. Available online: http://www.mapleridgemuseum.org/ 08_community/09/08_09_06_07_jackson.html\#nogo (accessed on 25 June 2013).

65. Fletcher, T. Albion Farm Ignites Rural-Urban Debate. Maple Ridge News, 31 May 2003, pp. $22-23$.

66. Provincial Agricultural Land Commission. Staff Report: Application \# 0-34894-0; File No: 0-34894-0, 1-3; B.C. Agricultural Land Commission: Burnaby, BC, Canada, 2003.

67. District of Maple Ridge. Staff Report: Lower Jackson Farm (24554 102nd Avenue) and Upper Jackson Farm (Lot A LMP 42378) at 100th Avenue and 248th Street; District of Maple Ridge: Maple Ridge, BC, Canada, 2009; pp. 1-13.

68. District of Maple Ridge. Official Community Plan. Available online: http://www.mapleridge.ca/ EN/main/business/4389/ocp.html (accessed on 25 June 2013).

69. District of Maple Ridge. Staff Report: Application to Exclude Land from the Agricultural Land Reserve-24554 \& 24572102 Avenue (Jackson Farm); File No: AL/087/02, 1-6; District of Maple Ridge: Maple Ridge, BC, Canada, 2002.

70. District of Maple Ridge. Staff Report: Application to Exclude Land from the Agricultural Land Reserve-24554 \& 24572102 Ave (Jackson Farm); File No: AL/087/02, 1-3; District of Maple Ridge: Maple Ridge, BC, Canada, 2003.

71. Barnes, T. Jackson Farm Sent to the ALC. Maple Ridge Pitt-Meadows Times 30 May 2003.

72. Provincial Agricultural Land Commission. Staff Report Supplement: Application \# 0-34894-0; File No: 0-34894-0, 1; B.C. Agricultural Land Commission: Burnaby, BC, Canada, 2003.

73. Metro Vancouver. Memorandum Greater Vancouver Regional District: Application \#0-34894-0 Exclusion of 15.2 HA of ALR Lands (Jackson Farm); File No: CP 11-01-RCS-Maple Ridge; Metro Vancouver: Burnaby, BC, Canada, 2003.

74. Metro Vancouver (Greater Vancouver Regional District). Livable Region Strategic Plan Implementation Agreement. Available online: http://www.metrovancouver.org/about/publications/ Publications/LRSP.pdf (accessed on 25 June 2013).

75. Metro Vancouver. Livable Region Strategic Plan; Metro Vancouver: Burnaby, BC, Canada, 1996.

76. Metro Vancouver. Request from the District of Maple Ridge to Amend the Green Zone Boundary of the Livable Region Strategic Plan. In Agenda: Greater Vancouver Regional District Public Hearing; Metro Vancouver: Burnaby, BC, Canada, 2008; pp. RD-1-RD-110.

77. BC Local Government Act. Greater Vancouver Regional District Regional Growth Strategy Exemption Regulation. Available online: http://www.bclaws.ca/EPLibraries/bclaws_new/ document/ID/freeside/377_2007 (accessed on 25 June 2013).

78. BC Provincial Government. Resumé of Order in Council: The Greater Vancouver Regional District Regional Growth Strategy Exemption Regulation, 2007. Available online: http://www.qp.gov.bc.ca/statreg/oic/2007/resume29.htm (accessed on 25 June 2013). 
79. Metro Vancouver. Supplemental Agenda Items to the July 18, 2008 Regular Board Meeting, GVRD Section A1-GVRD Section C8; Metro Vancouver: Burnaby, BC, Canada, 2008.

80. Metro Vancouver. Minutes of the Public Hearing of the Greater Vancouver Regional District (GVRD) Board of Directors; Metro Vancouver: Burnaby, BC, Canada, 2008; pp. 1-22.

81. Metro Vancouver. Staff Report: Response to Questions Raised at the September 17, 2008 Public Hearing on Bylaws to Amend the Green Zone of the Livable Region Strategic Plan in Maple Ridge; Metro Vancouver: Burnaby, BC, Canada, 2008.

82. Metro Vancouver. Minutes of the Regular Meeting of the Greater Vancouver Regional District (GVRD) Board of Directors; Metro Vancouver: Burnaby, BC, Canada, 2008; pp. 1-16.

83. District of Maple Ridge. Staff Report: First Reading-Maple Ridge Official Community Plan Amending Bylaw No. 6674-2009 and Maple Ridge Zone Amending Bylaw No. 6675-2009: 24554 102 Avenue (Lower Jackson Farm) \& Lot A LMP 42378 at 100 Avenue \& 248 Street (Upper Jackson Farm); File No: RZ/040/09, 1-8; District of Maple Ridge: Maple Ridge, BC, Canada, 2009.

84. Metro Vancouver. Staff Report: District of Maple Ridge Regional Context Statement Amendment Request; Metro Vancouver: Burnaby, BC, Canada, 2010; pp. 1-7.

85. Skelton, C. Controversial Jackson Farms Development Linked to Donations. Available online: http://www.canada.com/vancouversun/news/westcoastnews/story.html?id=3c5ef5aa-49c4-467abfdb-ab95e395c539 (accessed on 25 June 2013).

86. Campbell, S. Green cities, growing cities, just cities?: Urban planning and the contradictions of sustainable development. J. Am. Plan. Assoc. 1996, 62, 296-312.

87. Frenkel, A.; Orenstein, D.E. Can urban growth management work in an era of political and economic change? J. Am. Plan. Assoc. 2012, 78, 16-33.

88. Pearce, D. An intellectual history of environmental economics. Annu. Rev. Energy Environ. 2002, $27,57-81$.

89. Fowlie, J.B.C. Core review will look at Agricultural Land Research, among other 'sacrosanct things'. Vancouver Sun, 31 July 2013.

90. News Views: ALR Review Risky Business. Maple Ridge News, 13 August 2013.

91. Bunce, M.; Maurer, J. Prospects for Agriculture in the Toronto Region: The Farmer Perspective; Neptis Foundation: Toronto, ON, Canada, 2005.

(C) 2013 by the authors; licensee MDPI, Basel, Switzerland. This article is an open access article distributed under the terms and conditions of the Creative Commons Attribution license (http://creativecommons.org/licenses/by/3.0/). 